No $2000-10$

June

ET D'INFOEMATIONS

INTEENATIONALE

Big and Small Currencies: the Regional Connection

Agnès Bénassy-Quéré Benoît Coeuré 


\section{TABLE OF CONTENTS}

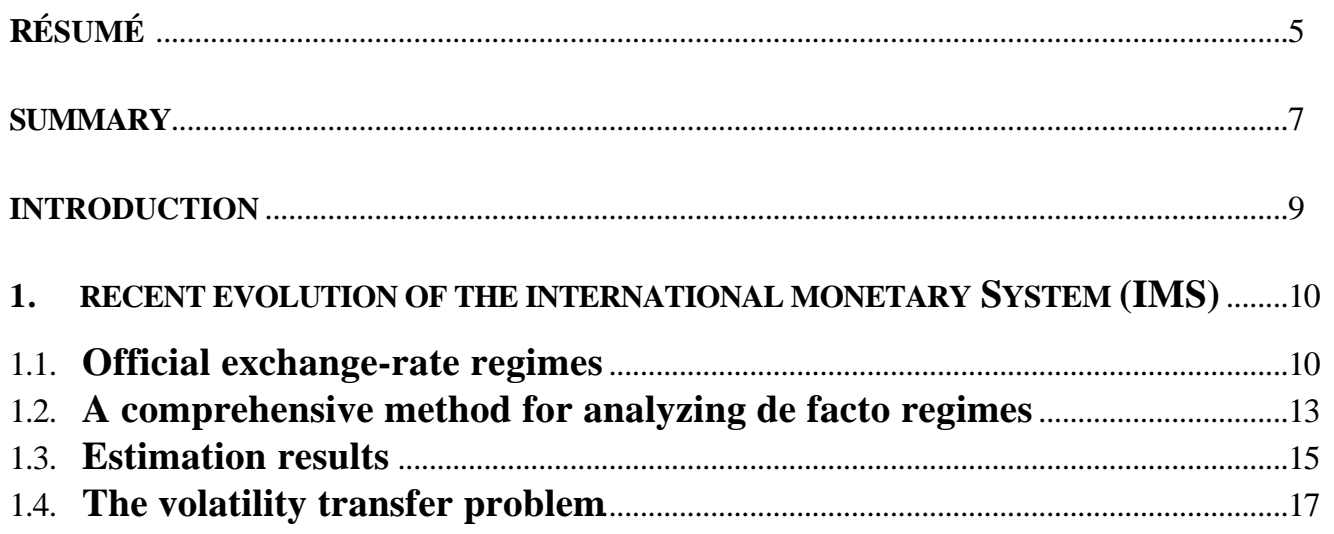

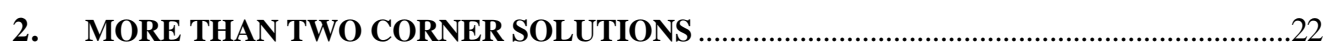

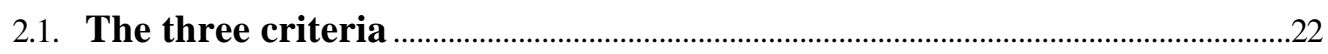

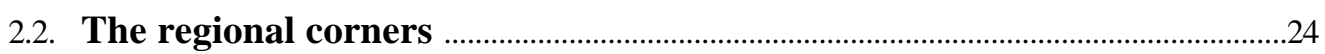

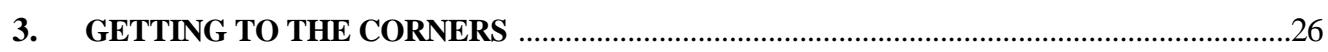

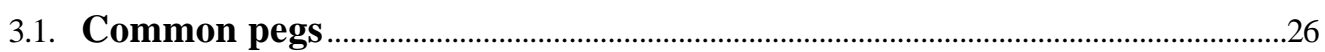

3.2. Institutions for regional integration........................................................................27

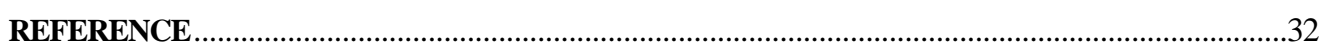

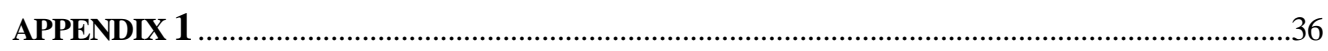

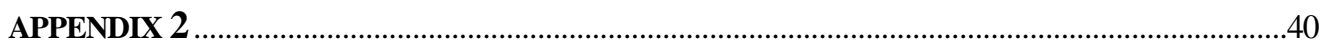

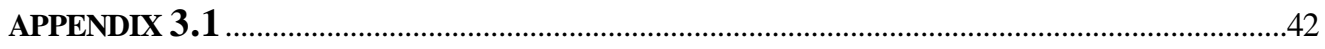

APPENDIX 3.2

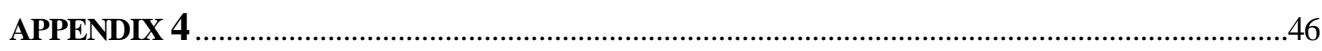

LIST OF WORKING PAPERS RELEASED BY THE CEPII..........................................................47 


\section{RÉSUMÉ}

On explore ici la dimension régionale de la nouvelle architecture financière internationale à la lumière du débat sur les "solutions en coin" pour les régimes de change, à l'occasion duquel certains prônent le flottement libre ou au contraire le currency board (ou la dollarisation) comme les seuls régimes tenables.

La première partie analyse l'évolution du système monétaire international (SMI) après les crises de change de 1997-1998, par comparaison avec la situation avant la crise. Les régimes de change suivis de facto sont étudiés àl'aide d'une méthode économétrique nouvelle fondée sur la méthode des moments généralisés. Les ancrages implicites de 111 monnaies sont estimés sur données hebdomadaires avant et après la période de crise. Les résultats montrent que la proportion de monnaies ancrées de facto au dollar US est beaucoup plus élevée que ne le laissent entendre les régimes officiels publiés par le FMI. Ce phénomène prévaut aussi après la crise asiatique, ce qui suggère que le système actuel survit beaucoup mieux aux chocs qu'on ne le pense habituellement, au moins à court terme. A l'inverse, les régimes de changes flottants sont beaucoup moins fréquents que ce qui est affiché officiellement, tandis que les ancrages sur l'euro représentent une substantielle minorité. On conclut que le SMI ne semble pas évoluer vers davantage de flottement, et qu'il est encore loin d'une configuration en différents blocs monétaires de tailles comparables.

L'impact des fluctuations des taux de change entre grandes monnaies sur la viabilité des régimes des «petites » monnaies a beaucoup été discuté. L'impact réciproque du comportement des «petites » monnaies sur la stabilité des grandes monnaies est moins souvent évoqué. On utilise ici un modèle simple de détermination du taux de change à long terme pour comparer l'effet de diverses configurations du SMI sur la volatilité du taux euro/dollar. On montre qu'une bi-polarisation des ancrages (euro/dollar) ou la généralisation d'ancrages sur des paniers pourrait accroître la volatilité de la parité euro/dollar, relativement à un système de flottement généralisé, mais aussi par rapport à un système centré sur le dollar. On conclut que les pays émergents pris dans leur ensemble sont confrontés àun dilemme : même si fixer leurs taux de change par rapport àl'une ou l'autre monnaie clé peut apparaitre comme une bonne solution si les monnaies clés ne varient pas trop entre elles, ces comportements d'ancrage risquent de déstabiliser leur environnement monétaire. Un moyen d'échapper à ce problème serait de construire des unions monétaires indépendantes des monnaies clés actuelles. Cela stabiliserait l'environnement monétaire interne à chaque région tout en assurant un véritable flottement des monnaies clés.

La deuxième partie étudie l'existence de solutions régionales pour les régimes de taux de change. Une fois la dimension régionale prise en compte, il existe plus de deux «solutions en coin ». En effet, la dimension régionale ajoute deux coins supplémentaires : l'union monétaire régionale, et l'union avec une monnaie clé - le dollar l'euro ou le yen. Même si ces deux coins constituent seulement des solutions de long terme, ils modifient radicalement les termes du choix d'un régime de change dès le court terme, de deux manières. D'une part, les deux solutions en coin traditionnelles peuvent s'avérer des obstacles à la marche vers les solutions régionales. D'autre part, la perspective d'une union monétaire dans le long terme peur rendre des régimes intermédiaires plus robustes dans le moyen terme, lorsque ces régimes sont correctement définis et gérés de manière coopérative.

La transition vers les «solutions en coin » régionales est étudiée dans la troisième partie du document. On distingue les pays autour de la zone euro (Europe de l'Est, pays méditerranéens) et les groupes de pays émergents fortement intégrés entre eux comme l'Asie de l'Est (hors Japon) ou l'Amérique du Sud. La coopération monétaire apparaît cruciale seulement dans le second cas, peut- 
être au travers d'ancrages souples sur des paniers communs. La coopération monétaire nécessite une confiance mutuelle au niveau de la politique économique, qui fait généralement défaut, en dépit de multiples expériences passées dans ce domaine. Un régime de change intermédiaire régional ne peut donc tenir que sur la base d'engagements fermes. Davantage de coordination des politiques économiques et de surveillance mutuelle favoriserait sans conteste un système régional, comme c'était le cas dans le système monétaire européen. Mais l'ancre d'un système régional devrait être au départ externe à la région émergente, par opposition au système européen. Enfin, le FMI devrait accompagner cette évolution en renforçant la dimension régionale de sa surveillance.

Mots clés : régimes de change, blocs monétaires, pays émergents.

Classification JEL : F33. 


\section{SUMMARY}

This paper is an exploration of the regional dimension of the new international financial architecture in the light of the debate on "two corner" solutions for exchange rate regimes, which advocates either free floating or currency boards (or dollarization) as the only sustainable regimes.

The first section deals with the evolution of the international monetary system (IMS) after 1997-1998 currency crises in emerging countries, as compared with the situation which prevailed prior to the Asian crisis. De facto exchange rate regimes are examined through the implementation of a new econometric methodology based on a method of moments. The implicit pegs of 111 currencies are estimated on weekly data over two periods (pre and post crises). Our results show that the proportion of currencies with de facto pegs on the US dollar is much higher and persistent than the share of the official pegs reported by the IMF. This is the case even after the Asian crisis, which suggests that the current system is much more resilient to shocks than it is usually thought, at least in the short run. Conversely, free floating appear much less frequent than claimed officially, whereas pegs on the euro are a significant minority. We conclude that the IMS is not moving towards a generalized free floating system, and it is still far from being organized around equally sized currency blocks.

The impact of exchange-rate fluctuations between key currencies on the sustainability of "small" currency regimes has been discussed extensively. The reverse impact of "small" currency regimes on the stability of key currencies is less frequently evoked. A stylized model of the long run exchange rate is used to compare the implication of various systems for the volatility of the euro/dollar exchange rate. It is shown that a general move towards dollarization/euroization or basket pegs may increase the volatility of the euro/dollar parity, compared to generalized floating and also to a hegemonic dollar system. We conclude that emerging countries as a whole face a dilemma: although fixing their exchange rates to one of the key currencies may seem a first best to them if these currencies were stable among them, such behavior would by itself result in a less stable environment. One way of escaping this problem would be to build monetary unions independently of key currencies. This would create stable regional environments while allowing key currencies to float against many currencies.

The second section explores the possibility of regional solutions for exchange-rate regimes. We argue that once the regional dimension is accounted for, there are more than two corner solutions. Indeed, the regional dimension adds two extra corners: the regional monetary union, and the union with a key currency --the dollar, the euro or the yen. Even though these corners are only long run solutions, they radically modify the terms of the choice of an exchange-rate regime even in the short run, in two ways. First, the "two corner" solutions may become an obstacle if the long run goal is a monetary union. Second, the perspective of a monetary union in the long run can make intermediate regimes more robust in the mean time, when these regimes are properly defined and managed through regional cooperation.

The transition towards regional corners is studied in the third section. A distinction is made between countries around the euro zone (Central and Eastern Europe, Mediterranean countries) and highly selfintegrated emerging regions such as East Asia (without Japan) or South America. Monetary cooperation is little necessary in the former case whereas it is crucial in the latter one, perhaps in the form of soft pegs on common baskets. Monetary cooperation needs mutual confidence at the policy level, which these regions lack, despite many experiments in this field. Hence, backing regional intermediate regimes would require strong commitments. Developing economic policy coordination 
and mutual surveillance would undoubtedly support a regional system, as it was the case in the European monetary system. However the anchor of regional systems would likely remain extraregional currencies in the short run, contrasting with the European case. Finally, the International Monetary Fund should accompany this evolution through increasing the regional dimension of its surveillance.

Keywords: $\quad$ Exchange rate regimes, currency blocks, emerging countries.

JEL classification: F33 


\title{
Big and Small Currencies: the Regional Connection
}

\author{
Agnès Bénassy-Quérêt(*) and Benô̂t Cou urêt(*)
}

\section{INTRODUCTION}

The International Monetary System (IMS) traditionally lags behind economic history. The US take off, already observed after World War I in the field of international trade and investment, materialized in the monetary area only after World War II, through the Bretton Woods agreement. But the dollar remained prominent even after the dollar gold standard collapsed in 1971, and after the collapse of the entire Bretton Woods system, in 1973. The dollar by far remained the main currency for international trade and investment, and the main anchor for monetary policies. European countries were the first to free themselves from the dollar wing through regional co-operation. But neither the Ecu nor the Deutschemark ever became international vehicles or widely used monetary anchors, even though regional integration also involved countries at the periphery of EMS. More strikingly, economic integration in Asia did not go along with monetary integration.

There are two possible interpretations of such a phenomenon. First, the internationalization process is subject to much inertia due to network externalities. Indeed, a currency is not more expensive when its international status is larger. On the contrary, it is generally cheaper to use it or to hold it due to lower transaction costs. Hence, the internationalization process is cumulative, and international currencies are hard to replace (Krugman, 1984). The alternative interpretation is that the European or maybe specifically French - view, which poses monetary integration as a factor of economic integration, is not universal. The Asian and South-American examples would show that the architecture of the IMS has little influence on real integration, but that, on the contrary, real integration leads sooner or later to the question of monetary integration.

Almost thirty years after the collapse of the Bretton Woods system, and three years after the beginning of the Asian crisis, the IMS should be mature for a re-shaping. Such re-shaping has already started: many countries have recently changed their exchange rate regime. Many were forced to do so by speculative attacks, but others just decided to do so, following a new view which advocates either

\footnotetext{
(*) CEPII, 9 rue Georges Pitard, 75015 Paris, a.benassy@ cepii.fr.

${ }^{(* *)}$ French Ministry of Economy, Finance and Industry. benoit.coeure@dt.finances.gouv.fr.
}

The opinions expressed in this paper are those of the authors only and do not commit the institutions they belong to. We are grateful to Julien Genet for research assistance, and to Patrick Allard, Stefan Collignon, Barry Eichengreen, Daniel Gros, Paul Masson, Pierre Morin, André Sapir and Charles Wyplosz for their remarks on an early version of this work. We also thank the participants of the IIE-CEPS-EPRU workshop on "The Dollar and the Euro", (Wahington D.C., April 17, 2000). All errors remain ours. 
free floating or currency boards (or even dollarization) as the only sustainable regimes (the so-called « two-corner solutions », see for instance Eichengreen, 1999). However it will be shown that genuine free floats have remained very scarce in practice, whereas de facto pegs on the dollar have remained prominent.

The speed of the re-shaping of the IMS will depend on inertia effects and on the perceived needs for monetary co-operation. The present paper aims at analyzing its regional dimension. We first look at the recent evolution of the IMS and at its possible impact on global stability (Section 1). We then examine the pros and cons of various forms of regional co-operation, (Section 2). Section 3 is devoted to examining how to implement regional co-operation or co-ordination. Section 4 provides concluding remarks.

\section{RECENT EVOLUTION OF THE INTERNATIONAL MONETARY SYSTEM (IMS)}

During the 1990s, the IMS was hit by three major shocks. The first one was the expansion of international capital flows at a much higher speed than the development of trade, ${ }^{1}$ the arrival of powerful players whose balance sheets exceed those of central banks, and subsequently the greater autonomy of the "bottom" of the balance of payments (foreign direct investment, portfolio investment) from the "top" of the balance (trade in goods and services). The second shock, which is partly related to the first one, was the financial crises in emerging economies (1994 in Mexico, 1997 in Asia, 1998 in Brazil and Russia), and the floating of many currencies previously pegged to the US dollar. The third one was the creation of the euro, which has become a key currency of the IMS. Given the large inertia of the internationalization process, the financial crisis should be the main driving force of the IMS in the short run. We investigate this force by comparing the evolution of exchange-rate regimes before and after the crises.

\subsection{Official exchange-rate regimes}

A first comprehensive view of exchange rate regimes in the world is provided by the publications of the International Monetary Fund (IMF), which classifies member countries according to the degree of flexibility of their currency. As noted by Eichengreen (1999), IMF classifications show that, since the 1970 s, the share of developing countries with a fixed exchange rate has declined steadily (from $90 \%$ in 1975 to $45 \%$ in 1997), whereas the share of flexible exchange rates has risen (from $10 \%$ in 1975 to $55 \%$ in 1997). Figure 1 below extends this diagnosis to all member countries over 1983-1999. It also shows that most switches occurred in the late 1980s-early 1990s. The relative share of both groups of regimes have stabilized since then, despite EMU (which mechanically reduced the proportion of limited flexibility regimes) and financial crises in emerging countries (which reduced the share of fixed pegs, see infra).

However this diagnosis is insufficient. First, these two groups mix exchange-rate regimes which are quite different. Second, the anchor currencies are not identified. Table 1 provides some detail on the scissor-like evolution illustrated in Figure 1. It confirms the striking extension of free floating regimes

\footnotetext{
1 Between 1989 and 1998, the average daily turnover on the foreign exchange markets (spot and derivative markets) tripled and reached USD 1500 billion in 1998, whereas daily world exports rose by $80 \%$ only (in nominal terms), over the same period (BIS, 1999).
} 
(where monetary authorities do not intervene repeatedly on the foreign exchange), at the expense mainly of pegs on baskets of foreign currencies. ${ }^{2}$ Fixed pegs on single currencies have better survived, due to the longevity of the French franc zone and to the creation of several currency boards in the 1990s. However the share of crawling pegs and managed floating regimes has resisted too, and it actually rose between 1994 an 1999.

The slight retreat of fixed pegs on a single currency is attributable to the dollar, although the euro did not benefit much from this movement. ${ }^{3}$ The scissors effect evidenced in Figure 1 hence can be described as a substitution of free and managed floating regimes to pegs on the US dollar and on baskets of foreign currencies. No evolution towards a multi-polar system is apparent in Table 1.

Figure 1

\section{Share of fixed and flexible regimes among IMF member countries (end of year)}

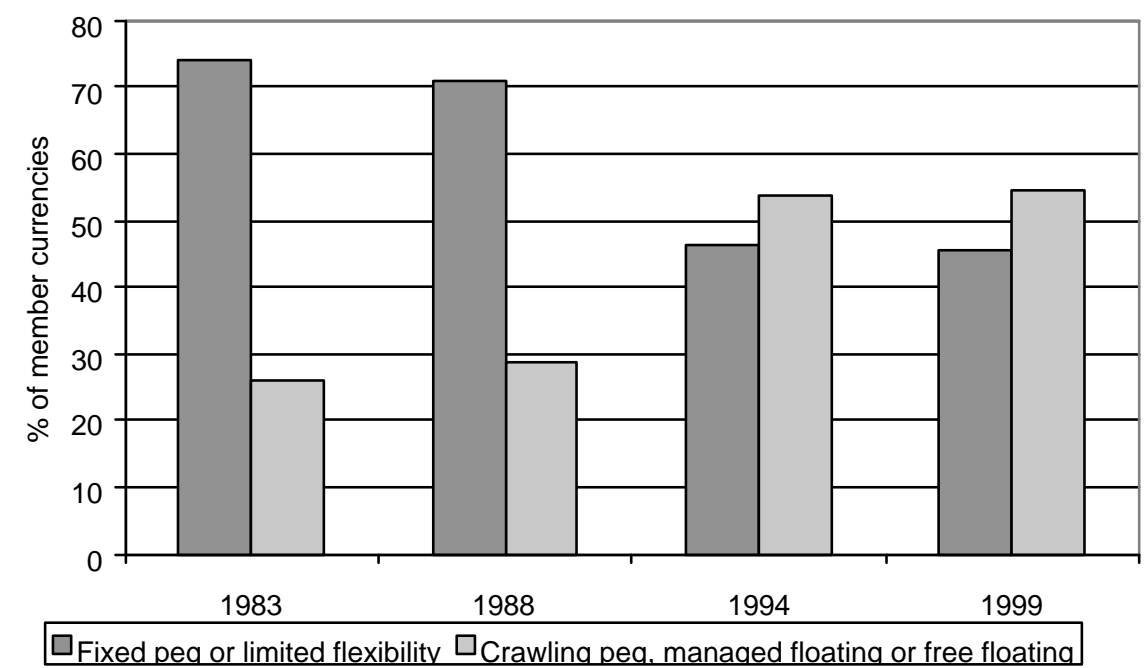

Sources: IMF, Annual Report on Exchange Arrangements and Exchange Restrictions, various issues. IMF, International Financial Statistics, October 1999.

\footnotetext{
${ }^{2}$ The retreat of limited flexibility regimes is essentially attributable to the merger of 11 currencies into the euro.

${ }^{3}$ The share of other currencies has remained stable due to regional arrangements around the South-African rand and the Indian rupee.
} 
Table 1: Share of various regimes among I MF member countries

(end of year)

\begin{tabular}{|c|c|c|c|c|}
\hline Exchange-rate regimes & 1983 & 1988 & 1994 & 1999 \\
\hline Fixed pegs on single currencies, including currency boards & 35.6 & 38.2 & 26.0 & 29.9 \\
\hline US dollar & 23.3 & 25.7 & 13.8 & 15.0 \\
\hline FF, DM, euro & 8.9 & 9.2 & 8.3 & 12.3 \\
\hline others & 3.4 & 3.3 & 3.9 & 2.7 \\
\hline Fixed pegs on baskets & 27.4 & 25.7 & 13.3 & 9.6 \\
\hline SDR & 8.9 & 5.3 & 1.7 & 3.2 \\
\hline ECU & 0.7 & 0.7 & 0.6 & - \\
\hline other baskets & 17.8 & 19.7 & 11.0 & 6.4 \\
\hline Limited flexibility & 11.0 & 7.2 & 7.2 & 5,9 \\
\hline European exchange-rate mechanism & 4.8 & 4.6 & 5.0 & 1.1 \\
\hline other arrangements with bands & 6.2 & 2.6 & 2.2 & 4.8 \\
\hline Crawling pegs, managed floats & 19.9 & 17.8 & 19.9 & 23.0 \\
\hline Free floats & 6.2 & 11.2 & 33.7 & 31.6 \\
\hline TOTAL & 100.0 & 100.0 & 100.0 & 100.0 \\
\hline Number of currencies & 146 & 152 & 181 & 187 \\
\hline
\end{tabular}

Sources: see Figure 1.

However managed floats may in practice modify this picture. In such a regime, there is no formal commitment from the authorities, but the intervention behavior of the latter may give birth to a de facto rule which is progressively interpreted as a commitment, like in Thailand before the 1997 crisis. In addition, the frontier between managed and free floating is rather vague. In theory, free floating means that the monetary authorities refrain from intervening in the foreign exchange market. In practice, it is more difficult to check whether there are interventions or not than to observe actual fluctuations (or stability) of the exchange rate. For instance, Korean authorities are known to have intervened on the won market despite their free floating regime, but this was not publicized and it can be found out only through econometric work (see Park et al., 1999). Conversely, a fixed regime with bands is close to free floating if the band is large (like in the ERM after August 1993) or if it is not credible.

The IMF is aware of these tricks, and now considers de facto policies in its classifications. For instance, the Egyptian pound is classified as pegged to the US dollar although its official regime is a managed float. ${ }^{4}$ Consistently, the empirical literature on exchange-rate regimes often considers de facto rather than de jure systems.

\footnotetext{
${ }^{4}$ The percentages reported in Figures 1 and 2 and in Table 1 however refer to official regimes in order to be consistent with historic data.
} 


\subsection{A comprehensive method for analyzing de facto regimes}

De facto regimes are generally identified through the estimation of an equation which relates the fluctuations of each currency $i$ to the fluctuation of various potential anchor currencies: ${ }^{5}$

$\dot{\mathrm{e}}_{\mathrm{ikt}}=\mathrm{a}_{0}+\mathrm{a}_{1} \dot{\mathrm{e}}_{\$ \mathrm{kt}}+\mathrm{a}_{2} \dot{\mathrm{e}}_{\mathrm{Ekt}}+\mathrm{a}_{3} \dot{\mathrm{e}}_{\mathrm{Ykt}}+\mathrm{u}_{\mathrm{t}}$

where $\dot{\mathrm{e}}_{\mathrm{ikt}}$ denotes the rate of variation of currency $i$ in terms of currency $k$ between $t-1$ et $t^{6}$ The constant term $a_{0}$ is positive if the exchange rate of $i$ regularly depreciates (or is regularly devalued) in order to compensate a positive inflation differential (in the case of a crawling peg for instance). The coefficients $a_{j}(j \neq 0)$ can then be interpreted as the share of each key currency $j$ in the implicit basket peg of country $i$. If none of the coefficient is significant, then $i$ can be interpreted as a floating currency. If one coefficients $a_{j}$ does not significantly differ from unity whereas all others are non significant, then $i$ is pegged to $j$. Lastly, if various coefficients are significant and bound by zero and one, then $i$ is pegged to a basket of the corresponding currencies.

Although very simple in principle, this method raises the tricky question of the numeraire $k$ (see Box). The methodology proposed in this paper does not rely on the choice of the numeraire: the three key currencies bear the same status. The method consists in directly testing for the stability of any currency $i$ in terms of a basket made of the US dollar, the euro and the yen:

$$
\alpha_{i}^{\prime} X_{i t}=\beta_{i}+u_{i t}
$$

where $X_{i t}=\left(\dot{\mathrm{e}}_{\mathrm{i} \$ \mathrm{t}}, \dot{\mathrm{e}}_{\mathrm{iEt}}, \dot{\mathrm{e}}_{\mathrm{iYt}}\right)^{\prime}, \alpha_{i}$ denotes the weighting vector and $\beta$ is a scalar. Equation (1.2) is estimated as an orthogonality condition using the generalized method of moments under the restriction $\sum_{\mathrm{j} i=1}^{3} \mathrm{a}_{\mathrm{ij}}=1$. It should be noted that the weights of this "effective exchange rate" are endogeneous and that our method does rely only on exchange rates versus the key currencies.

The estimation is carried out separately for 111 currencies. Exchange rates are observed at the end of each week, over two periods: April 1995 to June 1997 (before the Asian crisis), and October 1998 to December 1999 (after the bulk of financial crises in emerging countries). The euro is assimilated to the Ecu before January $\mathrm{f}^{\mathrm{t}}$ 1999. A Newey-West correction is used in order to account for the heteroskedasticity and auto-correlation of the residuals, which stem from the use of weekly day-end data. ${ }^{7}$ The methodology is detailed in Appendix $1 .^{8}$ A Student test is applied to each coefficient $\boldsymbol{\alpha}_{i j}$ in

\footnotetext{
5 More recently, Levy Yeyati and Sturzenegger (1999) use cluster analysis in order to produce a classification of exchange-rate regimes based on the volatility of exchange rates, of exchange-rate changes and of official reserves. This approach however focuses on the degree of flexibility rather than on the anchor currency. It does not estimate the weighting of basket pegs.

${ }^{6}$ Exchange rates are differentiated both for statistical reasons (exchange rates are generally found I(1)) and analytical reasons (in order to account for the various kinds of pegs, including crawling pegs). Alternative approaches include cointegration analysis (Aggarwal and Mougoué, 1993 ; Levasseur and Serranito, 1996) or studying the correlations of trends and of cyclical components of exchange rates (Girardin and Marimoutou, 1997). In all cases, there is a problem of numeraire.
}

7 A non-parametric method like that of Newey and West is advisable here since we do not estimate a model of determination of the exchange rate, but rather a statistical regularity. 
order to see whether it significantly differs from zero, i.e. if currency $j$ is included in the implicit basket peg of $i$. If $\boldsymbol{\alpha}_{i j}$ significantly differs from zero, then its equality to unity is tested (also through a Student test). If $\boldsymbol{\alpha}_{i j}$ does not significantly differ from unity, then $i$ is considered a unitary peg on $j$. If $\boldsymbol{\alpha}_{i j}$ differs from zero and one, $i$ is partially pegged to $j$, and the weight of $j$ in the implicit basket is $\boldsymbol{\alpha}_{i j}$. Lastly, if $\alpha_{i j}$ does not significantly differ from zero (whatever the conclusion of the test of equality to one), it can be concluded that country $i$ does consider currency $j$ in its exchange-rate policy.

It can be objected that choosing the null hypothesis of a unitary peg may induce a bias towards "pegging" in our results when the standard error of the estimates is high, which is the case in some countries.

Howewer, the main purpose of the study is to depart dollar pegs from euro or basket pegs, and an method is neutral to this respect.

\section{Box: The choice of the numeraire in the estimation of implicit basket pegs}

The following equation is to be estimated:

$\dot{\mathrm{e}}_{\mathrm{ik}}=\mathrm{a}_{0}+\mathrm{a}_{1} \dot{\mathrm{e}}_{\mathrm{Ek}}+\mathrm{a}_{2} \dot{\mathrm{e}}_{\mathrm{Yk}}+\mathrm{a}_{3} \dot{\mathrm{e}}_{\$ \mathrm{k}}+\mathrm{u}$

where $\dot{\mathrm{e}}_{\mathrm{ik}}$ denotes the rate of variation of currency $i$ against $k$ (the time index is dropped for tractability). The numeraire $k$ should not be linked to a currency of the basket (otherwise one of the exogenous variables has a small variance and may be confused with the constant term). According to this first criterion, the Swiss franc (which was linked to the DM over the past) should be excluded ${ }^{9}$, as well as the pound Sterling (partially linked to the dollar and to the DM) and the Australian dollar (linked to the US dollar). A solution can be to use a basket of currencies as the numeraire (the SDR in Frankel and Wei, 1995; a basket of five key currencies weighted by GDPs in Frankel et al., 1999). Because the dollar, the mark (or the euro) and the yen are obviously not pegged to a basket, the problem mentioned above is solved. Yet, if these three currencies are prominent in the numeraire, the right hand side of equation (B.1) can be null even when $i$ is not pegged to the numeraire. Noting B the basket, we get by definition:

$\dot{\mathrm{e}}_{\mathrm{iB}}=\mathrm{b}_{1} \dot{\mathrm{e}}_{\mathrm{i} \$}+\mathrm{b}_{2} \dot{\mathrm{e}}_{\mathrm{iE}}+\mathrm{b}_{3} \dot{\mathrm{e}}_{\mathrm{iY}} \quad 0<b_{i}<1$

which can be re-written:

8 Note that the estimated equation is linear: the coefficients are the same whether the currencies appreciate or depreciate. In a descriptive analysis, Takagi (1996) shows that, between 1982 and 1995, the Korean won and the Indonesian ringgit tended to follow the yen to a larger extent when the latter depreciated than when it appreciated, whereas the reverse applied to the Singaporean dollar.

9 See Galati (1999). Frankel and Wei (1994) use the Swiss franc as the numeraire, but this is not damaging since they study the case of countries which have to choose between the dollar and the yen (not the DM or the euro). In this case, however it would be more straightforward to take the DM or the euro, or, as done by Ohno (1999), to take the Swiss franc, but remove the DM from the set of explanatory variables. 


$$
\begin{aligned}
& \dot{\mathrm{e}}_{\mathrm{iB}}=\left(\mathrm{b}_{1}+\mathrm{b}_{2}+\mathrm{b}_{3}\right) \dot{\mathrm{e}}_{\mathrm{iB}}-\mathrm{b}_{1} \dot{\mathrm{e}}_{\$ \mathrm{E}}-\mathrm{b}_{2} \dot{\mathrm{e}}_{\mathrm{EB}}-\mathrm{b}_{3} \dot{\mathrm{e}}_{\mathrm{YB}} \\
& \text { If }\left(\mathrm{b}_{1}+\mathrm{b}_{2}+\mathrm{b}_{3}\right) \approx 1 \text {, then (B.3) is equivalent to: } \\
& \mathrm{b}_{1} \dot{\mathrm{e}}_{\$ \mathrm{~B}}+\mathrm{b}_{2} \dot{\mathrm{e}}_{\mathrm{EB}}+\mathrm{b}_{3} \dot{\mathrm{e}}_{\mathrm{YB}}=0
\end{aligned}
$$

The problem arises because the numeraire is possibly correlated with the basket peg.

Frankel (1993) chooses to express the exchange rates in terms of a common basket of goods. But then, estimated pegs are real pegs.

The last solution consists in selecting one of the potential anchor currencies as the numeraire. In this vein, Bénassy-Quéré (1999a) runs the following estimation:

$$
\dot{\mathrm{e}}_{\mathrm{i} \$}=\mathrm{a}_{0}+\mathrm{a}_{1} \dot{\mathrm{e}}_{\mathrm{E} \$}+\mathrm{a}_{2} \dot{\mathrm{e}}_{\mathrm{Y} \$}+\mathrm{u}
$$

This specification highlights the role of the euro and of the yen as anchor currencies. For instance, $a_{I}$ $=0.5$ means that currency $i$ depreciates by $5 \%$ against the dollar when the latter appreciates by $10 \%$ against the euro: it partially follows the euro. Yet, the $a_{i}$ coefficients cannot be interpreted as weights in an implicit basket peg. In addition, this method does not allow to distinguish a peg on the dollar from a free floating regime. In both cases, $a_{l}$ and $a_{2}$ do not significantly differ from zero, whereas $a_{0}$ can be either null or positive (in the case of a positive inflation differential); the only difference is the variance of the residuals $u$, but no precise criterion can be used. It is always possible, in a second stage, to use the euro or the yen as the numeraire. But the estimates obtained can be inconsistent with those obtained with the dollar, due to the correlation between the explanatory variables, and it is difficult to conclude since the tests are not nested together.

\subsection{Estimation results}

The results are summarized in Table 2 (see the detailed results in Appendices 2 and 3). They are presented as a percentage of the total number of currencies in order to allow for a comparison with Table 1. Of course, the various currencies bear very different weights in the world economy. Trade weighted results are presented in the next section. Besides, identified "pegs" are only statistical regularities and do not necessarily correspond to official policies of the correspondant countries.

- Whatever the period under consideration, the proportion of currencies with unitary coefficients on the US dollar (50\%) is much higher than the share of official pegs to the dollar as reported in Table 1 (15\% in 1999), and it is rather stable. This phenomenon uncovers de facto pegs on the US currency. It includes the case of Brazil, Korea and Mexico over the post-crisis period (see the detailed table in Appendix). The proportion of non-unitary peggers decreased from $12.1 \%$ in the first period to $6.5 \%$ in the second period.

- Despite the absence of most ERM currencies in the sample, and despite the grouping of the French franc zone in a single country (instead of 14 in Table 1), the proportion of currencies which are pegged to the euro is equivalent to that in Table 1, which means that several currencies are pegged de facto but not de jure on the euro. The detailed table in Appendix shows that it is 
the case of the Czech republic, Cyprus, Denmark, Greece, Norway, Slovenia, Slovakia, Sweden and Switzerland, at least over the second period.

- The proportion of basket peggers is higher than in Table 1. The most popular basket is a eurodollar one. When included in the basket, the yen generally bears a small weight. Nevertheless, the proportion of pegs to a euro-dollar-yen basket has increased substantially in the second period.

- Free floating appears much less frequent in Table 2 (4\%) than in Table 1 (30\%). One interpretation is that most countries are integrated to one or several of the three anchor countries or zones, so their exchange rates tend to be relatively stable against the corresponding anchor. This first interpretation appears likely for countries such as Mexico or Switzerland. However this interpretation is rather fragile for emerging market countries, the economic structures of which differ substantially from that of industrial countries. In addition, less than $50 \%$ of third countries are closely integrated with the United States. The alternative interpretation is that few countries refrain from intervening on the foreign exchange market, even when they pretend to follow a floating regime.

In sum, our results are rather different from the official picture: there is no trend towards more floats or less pegs on the US dollar, and the latter regime remains prominent in the IMS. These results are consistent with those of Levy Yeyati and Sturzenegger (1999) who find many cases of de facto pegged currencies and no gradual disappearance of intermediate regimes, and of Masson (2000) whose dynamic analysis also questions the "hollowing out" hypothesis. Here, it is clear that the IMS is not moving towards a generalized floating system, and that it is still far from being organized around equally sized currency blocks. Our findings confirm that the IMS is prone to strong inertia, even when hit by large shocks. However our time span is rather short, and it is not inconsistent with a slow move towards more floats or a bipolar system. In the next section, we study the implications of various systems for the euro/dollar instability. 
Table 2

De facto regimes ( $\%$ of currencies under review)

\begin{tabular}{lcc}
\hline \multicolumn{1}{c}{ Pays } & $\begin{array}{c}\text { April 1995-June 1997 } \\
\text { (before Asian crisis) }\end{array}$ & $\begin{array}{c}\text { Oct. 1998-Dec. 1999 } \\
\text { (after Asian crisis) }\end{array}$ \\
\hline Unitary peg on a single currency $\left(\alpha_{\mathrm{ij}}=1\right)$ & & \\
- US dollar & 50.6 & 49.5 \\
- euro & 10.3 & 10.3 \\
- yen & 0.9 & 0.0 \\
Partial peg on a single currency $\left(\alpha_{\mathrm{ij}}>0\right)$ & 12.1 & 6.5 \\
- US dollar & 0.9 & 1.9 \\
- euro & 0.0 & 0.9 \\
- yen & 12.1 & 14.0 \\
Peg on a basket $\left(\alpha_{\mathrm{ij}}, \alpha_{\mathrm{ij}}>0\right)$ & 5.6 & 2.8 \\
- dollar/leuro & 1.9 & 2.8 \\
- dollar/yen & 0.9 & 7.5 \\
- euro/yen & & 3.7 \\
- euro/dollar/yen & 4.7 & 100.0 \\
Free floating $\left(\alpha_{\mathrm{ij}}=0\right.$ or $\left.<0 \forall \mathrm{j}\right)$ & 100.0 & 107 \\
\hline Total & 107 & \\
\hline Number of currencies & & \\
\hline
\end{tabular}

Note: the French franc zone is considered as a single country (one estimation). Negative coefficients are not considered as partial pegs.

Source: own calculations.

\subsection{The volatility transfer problem}

The impact of exchange-rate fluctuations between key currencies on the sustainability of «small» currency regimes has been discussed extensively. The reverse impact of « small » currency regimes on the stability of key currencies is less frequently evoked. ${ }^{10}$ Two view can be contrasted.

The first view is that of Kindleberger (1973), according to whom the Great Depression was due to the lack of economic leadership at that time, after the weakening of the United Kingdom and before the rise of the United States. For Kindleberger, the existence of a dominant power is stabilizing since the corresponding country can impose some co-operation to its partner while supporting most of its costs:

«In these circumstances, the international economic and monetary system needs a leadership, a country which is prepared, consciously or unconsciously, under some system of rules that it has internalized, to set standards of conduct for other countries; and to seek to get others to follow them, to take on an undue share of the burdens of the system, and in particular to take on its support in adversity by accepting its redundant commodities, maintaining a flow of investment capital and discounting its paper. Britain performed this role in the century to

\footnotetext{
${ }^{10}$ The pros and cons of exchange-rate stability are well reviewed by Honohan and Lane (1999). They do not apply in the same way for industrial countries and for emerging countries. Hence, one should be concerned by the volatility transfer hypothesis.
} 
1913; the United States in the period after Second World War to, say, the Interest Equalization Tax in 1963. » (Kindleberger, 1973, p. 28).

According to Kindleberger, amongst the tasks of the leader, one is to implement a system of relatively stable exchange rates.

The second view is that of the volatility transfer (Fratianni and Von Hagen, 1990). The idea is that the exchange rate is an adjustment variable: fixing it transfers the burden of the adjustment to other variables, especially on other exchange rates. Considering the balance-of-payments equilibrium, Collignon (1999) shows that even the fundamental equilibrium exchange rate (FEER) is more volatile when some exchange rates are fixed, because remaining exchange-rate fluctuations are less able to bring the current account back to balance. ${ }^{11}$ This view is illustrated here in the case of two countries or zones.

In each country, the current account (standardized by GDP) is positively related to the real, bilateral exchange rate $q$, and it is submitted to permanent shocks $b_{0}{ }^{12}$ With stars denoting the foreign country, we have:

$$
\begin{array}{ll}
\mathrm{b}=\text { nää}(-\ddot{\mathrm{e}}) \mathrm{q}+\mathrm{b}_{0} & 0<\ddot{\mathrm{e}}<1 \\
\mathrm{~b}^{*}=-\mathrm{n} * \ddot{\mathrm{a}}\left(1-\ddot{e}^{*}\right) \mathrm{q}+\mathrm{b}_{0}^{*} & 0<\ddot{e}^{*}<1
\end{array}
$$

where $n\left(n^{*}\right)$ is the export-to-GDP ratio, $\delta$ is the sum of price-elasticities of exports and imports minus one (assumed positive in the long run and equal in the two countries) and $\lambda\left(\lambda^{*}\right)$ is the proportion of trade which is carried out with each monetary block (i.e with countries whose currencies are pegged to the euro and to the dollar respectively). Hence, $(1-\lambda) q$ represents the effective exchange rate deviation from baseline. ${ }^{13}$

We assume that in the long run, there are no net capital flows between the two countries (assuming a constant, sustainable value would not change the conclusion). Hence, we have:

$$
\mathrm{b}-\mathrm{b}^{*}=0
$$

\footnotetext{
${ }^{11}$ The FEER is defined as the exchange rate that is consistent with external and internal equilibrium (see Williamson, 1983). More volatility of the FEER would not necessarily transfer into higher short run volatility. This possibility is left for further research.

${ }^{12}$ Temporary shocks are not considered here because they have no impact on the FEER which is a longrun concept.

${ }^{13}$ Pegged currencies are assumed to be able to devalue in the long run in order to compensate for cumulated inflation differentials (like in the ERM).
} 
The FEER can be derived from (2.1) to (2.3): ${ }^{14}$

$$
\begin{aligned}
& \overline{\mathrm{q}}=-\frac{\mathrm{b}_{0}-\mathrm{b}_{0}^{*}}{\ddot{\mathrm{a}} \ddot{\mathrm{E}}} \\
& \text { with: } \ddot{\mathrm{E}}=\mathrm{n}(1-\ddot{\mathrm{e}})+\mathrm{n} *\left(1-\ddot{\mathrm{e}}^{*}\right)
\end{aligned}
$$

Equation (2.4) shows that the impact of asymmetric trade shocks is larger, the larger the proportion of currencies which are pegged to one of the two currencies. $\lambda$ and $\lambda *$ can be computed on the basis of the estimates obtained in Section 1. More specifically, we have:

$$
\ddot{\mathrm{e}}=\sum_{\mathrm{i}=1}^{\mathrm{N}} \mathrm{a}_{\mathrm{i}} \frac{\mathrm{X}_{\mathrm{i}}}{\mathrm{X}} \text { and } \quad \ddot{\mathrm{e}}^{*}=\sum_{\mathrm{i}=1}^{\mathrm{N}} \mathrm{a}_{\mathrm{i}}^{*} \frac{\mathrm{X}_{\mathrm{i}}^{*}}{\mathrm{X}^{*}}
$$

where $N$ is the number of "small" currencies in our sample $(\mathrm{N}=107$ after reducing the sample to currencies for which econometric results are available over both periods). $\alpha_{i}\left(\alpha_{i}^{*}\right)$ is the share of the euro (the dollar) in the implicit basket peg of currency $i$ (see Appendix 2), $X_{i}\left(X_{i}^{*}\right)$ represents exports of the euro-zone (or the United States) to country $i$ in current dollars, and $X\left(X^{*}\right)$ is the total of eurozone (or US) exports, in current dollars too (Source IMF). Alternatively, $\lambda$ and $\lambda^{*}$ can be calculated on an import basis. Hence, $\lambda$ and $\lambda^{*}$ represents the share of euro-zone (US) exports which are directed to the euro (dollar) block, or alternatively, the share of euro-zone (US) imports originating from the euro (dollar) block. These measures are comprehensive in the sense that they take basket pegs, partial pegs, negative relationships and over-reactions into account.

The results are summarized in Figure 2. The share of the dollar block in both exports and imports of the United States is high (72\% and 66\% respectively) and stable over the two periods, whereas the share of the euro block in exports and imports of the euro zone is rather low (around 20\%), although it has been rising in the second period mainly due to the inclusion of Switzerland in the euro block. ${ }^{15}$

\footnotetext{
${ }^{14}$ Here, bilateral exchange rate depends on bilateral disequilibria. For instance, a current account of $-4 \%$ in the United States and 0\% in the euro zone leads to the same euro/dollar exchange rate as a current account of $0 \%$ in the United States and $+4 \%$ in the euro zone.

${ }^{15}$ Before EMU, the Swiss franc was informally linked to the DM, but not to the Ecu.
} 


\section{Figure 2}

\section{Share of each currency block in the exports and imports} of the anchor country or zone
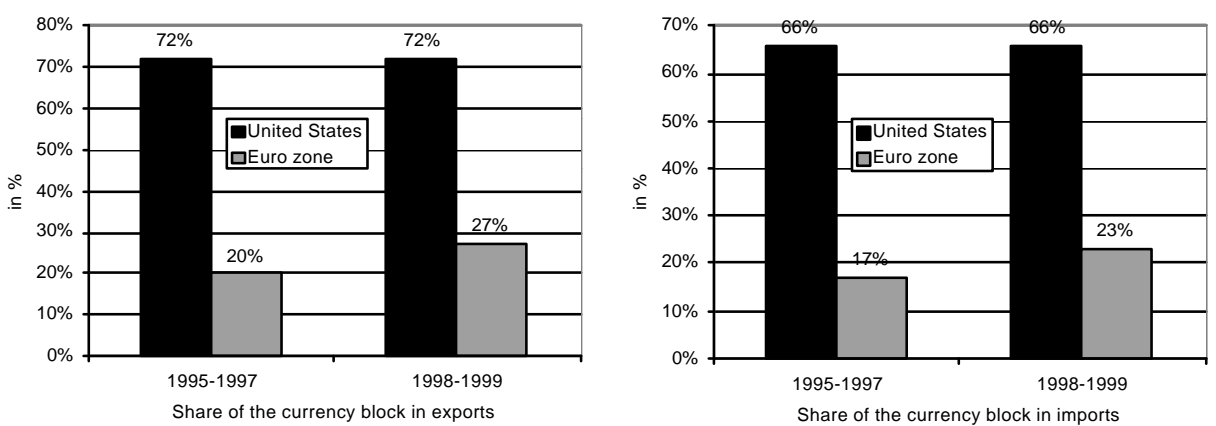

Source: own calculations.

Here we consider the average of $\lambda\left(\lambda^{*}\right)$ calculated from imports and exports; we use openness ratios of $10.9 \%$ for the United Sates and $17.8 \%$ for the euro zone (exports of goods and services over GDP, see Gros and Weiner, 2000), and we take $\delta=1 .^{16}$

This yields $\Lambda=0.18$ over $1995-1997$ and 0.17 over $1998-1999$. With no currency pegged to the dollar or to the euro, $\Lambda$ would be equal to 0.29 (the sum of the two openness ratios). A $1 \%$ of GDP shock on the current account would lead therefore to a $3.5 \%$ variation of the euro/dollar FEER. The reaction of the FEER reaches $5.6 \%$ with $\Lambda=0.18$ and $6.0 \%$ with

$\Lambda=0.17$. Hence, block floating increases the volatility of the FEER for a given magnitude of shocks to the current account.

Should the IMS move to a balanced bi-polar system with $\lambda=\lambda *=0.5$ (meaning that half of the trade of the euro area is directed towards the euro block, and half of US trade is directed towards the dollar block), then $\Lambda$ would fall to 0.14 , and a $1 \%$ shock on the bilateral current account would raise the exchange-rate reaction to $7.0 \%$. Conversely, coming back to a hegemonic system where all currencies but the euro would be pegged to the USD would raise $\Lambda$ to 0.20 , and the reaction of the euro/dollar FEER to the same shock would be only $5.1 \%$.

These various scenarios are summarized in Figure 3. It is clear from this figure that the most stable system for the euro/dollar couple in the long run would be a generalized float, consistently with the volatility-transfer hypothesis. But a hegemonic system appears more stabilizing for the euro/dollar exchange rate than a bi-polar system. The latter result confirms Kindleberger's "stabilizing hegemony" hypothesis, however not through the same channel: Kindleberger stresses the role of the hegemon in imposing co-operation and bearing its cost more than proportionally, whereas here the stabilizing virtue of hegemony stems from the relatively low degree of openness of the hegemon (the United

\footnotetext{
${ }^{16}$ Hence, we assume that the Marshall-Lerner condition hold in the long run. Taking another positive value for $\delta$ would not modify the volatility ratios across currency regimes.
} 
States) when compared to its challenger (the euro zone). ${ }^{17}$ The present system appears in-between hegemony and balanced bi-polarity. It could evolve into the latter if growing euro/dollar instability was to lead third countries to move from dollar pegs towards euro or basket pegs: the euro/dollar volatility would then endogenously increase.

From the above analysis, it can be concluded that emerging countries as a whole face a dilemma: although fixing their exchange rates to one of the key currencies may seem a first best to them if these currencies were stable among them, such behavior would by itself result in a less stable environment. ${ }^{18}$ One way of escaping this problem would be to build monetary unions independently of key currencies. This would create stable regional environments while allowing key currencies to float against regional currencies. We explore this possibility in the next section.

Figure 3

Reaction of the euro/dollar FEER to a 1\%-of-GDP shock on the bilateral current account

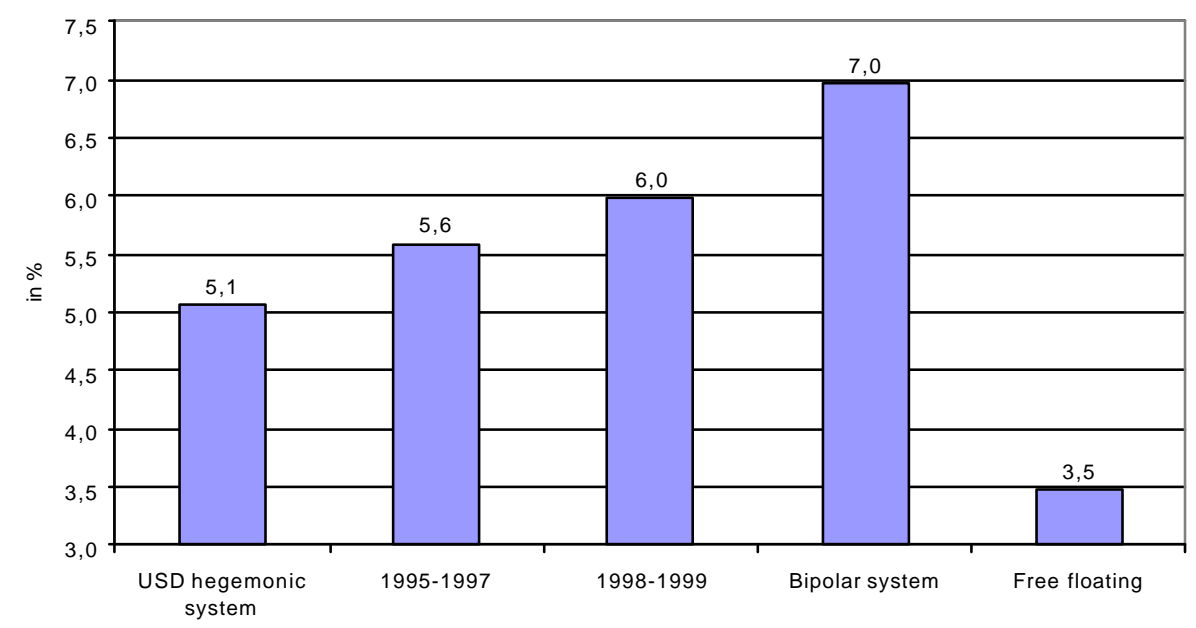

Source: own calculations.

\footnotetext{
${ }^{17}$ A hegemonic system centered on the euro would be even more destablizing for the euro/dollar exchange rate.

${ }^{18}$ Indeed, Bénassy-Quéré, Fontagné and Lahrèche-Révil (1999) show that currency blocks may increase foreign direct investment in emerging countries due to increased opportunities of risk diversification. Hence, a trade-off is to be made between regional stability and growth in the one hand, euro/dollar stability in the other hand. Once the United Stated and the Euro zone want to enjoy bilateral flexibility (rather than fixing the euro/dollar rate), they must be prepared to high volatility stemming from third currencies pegs, at least as a transition towards the building of independent currency blocks. See below.
} 


\section{MORE THAN TWO CORNER SOLUTIONS}

The traditional "two-corner" analysis stresses the importance of the commitment of monetary and political authorities to a given exchange rate regime. We argue below that two other criteria can usefully be considered when selecting an exchange rate regime: first, should the monetary anchor be internal or external? second, is the regime going to be part of a regional co-ordination? These three criteria are successively examined below. They produce eight instead of two corner solutions. We then compare four out of these eight solutions.

\subsection{The three criteria}

\section{A. The monetary anchor}

The argumentation in favor of fixed exchange rates generally relies on the need for a monetary anchor, in countries where the credibility of the central bank is not well established. A peg provides a transparent monetary target. It can be observed without delay and without measurement errors (contrasting with an inflation rate for which the measurement can be questioned). Provided the anchor currency performs well in terms of price stability, the peg allows disinflation to be imported through added credibility and a stable price of imported inputs. The latter effect is more effective in relatively open countries where the peg has little real effect (McKinnon, 1963). In relatively large countries, the external peg can still be effective through the credibility effect, as it is the case in Argentina.

However the case for external anchors is now much weaker than in the early 1990s. First, the effectiveness of pegged nominal exchange rates to enforce disinflation has been put into question (Masson, 1999). Second and more importantly, the 1992/1993 crises in the ERM, the 1994/95 Mexican crisis and the 1997/98 Asian, Latin American and Russian crises shed new light on the moral hazard intrinsic to fixed exchange rate regimes. These regimes provided implicit guarantees to foreign currency liabilities, making regime changes all the more costly for the real economy. Accordingly, in the academic field, "second generation" models of exchange rate crises ${ }^{19}$ have incorporated multiple equilibria and a sensitiveness to shifts in market expectations, whereas incoming "third generation" models also include destabilizing balance sheet or liquidity effects.

\section{B. The degree of commitment}

Most professional international economists now consider that fixed exchange-rate regimes are doomed to failure if they are not backed by strongly binding institutional arrangements such as currency boards, see Eichengreen (1999) for such a view. Pros and cons of currency boards are well known: imported disinflation and low risk premia on international debt have to be weighted against the loss of macroeconomic flexibility and of some useful functions of the central bank, such as last resort lending to distressed banks. This advocates currency boards only for small countries with a very flexible economy or when the credibility of the central bank has to be built from scrap, examples being the creation of a new currency or the recovery from hyperinflation (see Jadresic, Masson and Mauro, 1999, or Frankel, 1999).

The last step is to replace the domestic currency by the dollar or the euro in order to suppress the remaining uncertainties on the credibility of the exchange rate regime ("dollarization"). Such solutions

\footnotetext{
${ }^{19}$ In contrast to "first generation" models which insisted on the unsustainability of fixed exchange rates when fundamentals are changing, for instance when domestic credit is growing too fast.
} 
have been proposed since 1998 for Latin America (in Argentina and to a lesser extent in Mexico), and sometimes also for Eastern European economies and the Balkans (Dornbusch and Giavazzi, 1999). Some small countries or economies have made practical steps in this direction as witnessed by the introduction of the euro (under its DM denomination) in Kosovo and in Montenegro, and the dollarization of Ecuador.

\section{Regional cooperation}

From the above analysis, it can be concluded that the choice between an internal and an external monetary anchor is not independent from the type of commitment: an external target is viable only under a very strong commitment. If monetary authorities do not wish such a strong commitment, then they should opt for a free floating regime. This is exactly the "two-corner solutions" line of reasoning.

However, there are various types of commitment, depending on whether they are unilateral or multilateral (within a regional agreement). The regional equivalent to dollarization is monetary union. In this case, the single, regional currency is not anchored to an external currency but to regional monetary policy. ${ }^{20}$ In the special case where a small currency joins a pre-existing monetary union, the monetary anchor can be considered as external by the new entrant. The regime is then close to dollarization, except that the joining country has a marginal stake in monetary policy-making (Figure 4).

We now have a full description of exchange rate regimes according to the three criteria. ${ }^{21}$ The current common wisdom is that regimes with a weak commitment, as was the case of most intermediate regimes before the Asian crisis, are not viable. This leaves only two or three unilateral corner solutions (including free float with inflation targeting which, arguably, entails a certain degree of commitment). The regional dimension now adds two extra corners: the regional monetary union, and the union with a key currency - the dollar, the euro, or the yen.

\footnotetext{
${ }^{20}$ This can be true also of intermediate regimes if they have a regional dimension: the initial view of the EMS, and indeed the political one, was that the anchor was not the DM but the system itself.

${ }^{21}$ Two of the eight solutions are not commented on here because they are clearly not feasible. These are regional cooperation regimes without commitments.
} 


\section{Figure 4}

The menu of exchange rate regimes

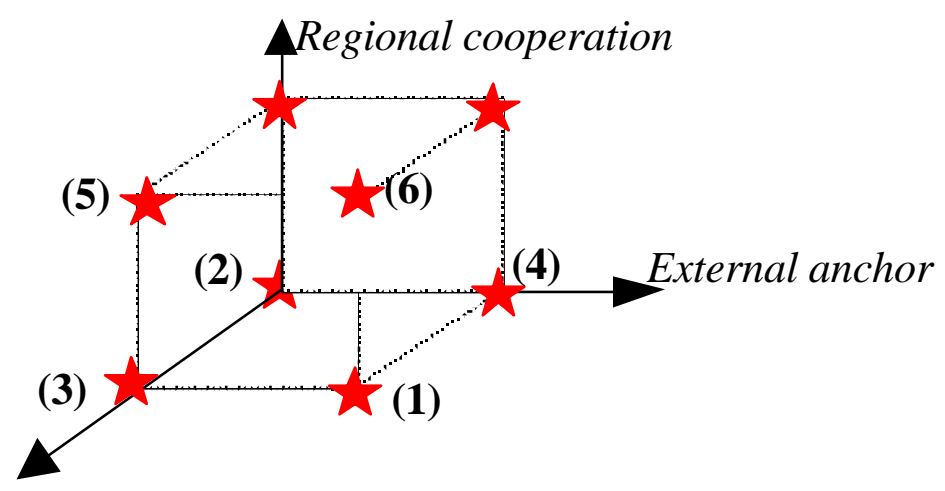

Commitment

Notes:

- The traditional "corner solutions" are (1) currency board arrangement (e.g. Hong Kong, Argentina, Estonia) and (2) free float or (3) free float with inflation targeting (UK, Brazil)

- Other solutions are (4) "old style" intermediate regime (e.g. Thailand pre-1997); (5) regional monetary union (EMU); (6) marginal membership to a monetary union (Greece).

\subsection{The regional corners}

Are regional monetary unions feasible outside Europe? According to Eichengreen and Bayoumi (1999b), East Asia (Japan excluded) is not in a very different situation from Europe vis-à-vis the traditional criteria of optimum currency areas (trade and financial integration, symmetry of macroeconomic shocks, factor mobility). This is not the case for instance in Middle-East and NorthAfrican (MENA) or in Caribbean countries, which lack intra-regional trade flows and labor mobility (Sadeh, 1997; Anthony and Hughes Hallett, 2000). In all cases, the European experience shows that, even in a highly integrated area, the road towards monetary union is very long. ${ }^{22}$ In addition, a country will not share its monetary sovereignty unless the quality of the new currency is at least as good as that of its domestic currency. The quality of the new currency can be guessed on the basis of the performance and governance of the existing central banks of the regional partners, and more generally on the basis of the economic and political environment in these countries. In sum, creating purely regional monetary unions is not realistic in the short run in emerging market countries due to the lack of confidence in the resulting regional single currencies: in a world where currencies are no longer anchored on gold or silver, there is a need for high reciprocal confidence prior to a monetary unification.

Now, are monetary unions feasible between emerging and industrial countries? According to Eichengreen and Bayoumi (1999a), a monetary union between East Asian countries (other than Japan)

${ }^{22}$ There has been thirty years between the first monetary union project (the Werner plan) and the introduction of the euro. 
and the United States would make sense from the Asian point of view. In the same vein, Boone and Maurel (1999) show that the business cycles in the Central and Eastern European Countries (CEECs) are highly correlated with German business cycles (less with euro-zone cycles).

Yet, a reciprocal agreement is needed for unifying monetary policies. Accounting for this double constraint, Artis and Mélitz (1999) show that, following the theory of optimum currency areas, the United States have little incentive to conclude a monetary union with any country given that the US economy is already rather closed. ${ }^{23}$ In addition, the Federal Reserve System and the ECB have no political mandate to share the responsibility for monetary policy with some emerging countries. Illustrations are the mitigated reaction of the Fed to the dollarization plans in some Latin American countries, or of the European authorities concerning euroization plans in some CEECs or in the Balkans. In the latter case, structural and nominal convergence are put forward prior to an integration into EMU. Structural phenomena such as the Balassa-Samuelson effect are often mentioned to suggest that premature monetary integration would be costly and maybe not sustainable in these countries unless their economy is extremely flexible, and that it would raise the average inflation in the euro zone.

A regional monetary union can constitute a long-run focal point for countries in South America or in East Asia. Entering EMU is certainly a long-run objective for the CEECs. In the short run, however, countries with "small" currencies will have to refrain the ambition of a purely regional co-operation and consider unilaterally their relationships with "big" currencies.

Still, the possibility of long term regional solutions radically modify the terms of the choice of an exchange-rate regime even in the short run, in two ways:

- Firstly, the unilateral "two corner solutions" may become an obstacle if the long run goal is a monetary union. On the one hand, the Asian experience has shown that free floating induces noncooperative strategies, especially when the region faces a common shock. On the other hand, dollarization is almost irreversible and even currency boards may become so because they lack an exit strategy, as exemplified by Argentina. Hence, it is suited only for a country which aims at joining a monetary union with the anchor currency in a not too far future, as it is the case for some CEECs.

- Secondly, the perspective of a monetary union in the long run can make intermediate regimes more robust in the mean time, when these regimes are properly defined and managed through regional co-operation. This point is studied in more detail in the next section.

\footnotetext{
${ }^{23}$ Honahan (1999) challenges this view on the European case through defining «mini-blocs » at the fringe of EMU: although exchange-rate stability with an extra-EMU country is generally unimportant for the euro zone as a whole, it can be useful for limiting asymmetric shocks.
} 


\section{GETTING TO THE CORNERS}

We conclude from Section 2.2 that the two corner solutions may not be optimal in a dynamic perspective, once the regional dimension is taken into account. We study here how the transition towards regional corners could be organized.

\subsection{Common pegs}

The main objective of a regional monetary arrangement is to provide relatively stable exchange rates within the regions, and a structure to organize coordinated realignments. It has been argued above that, in the sort run, this can be achieved only through the use of external anchors.

In a highly integrated region, the selection of a specific foreign anchor is of secondary importance. The most important thing is to use a common anchor in order to stabilize intra-regional exchange rates. In this vein, Williamson (1999) shows that a common basket for nine Asian countries would yield similar stability of effective exchange rates as would specific baskets adapted to each of the nine countries. However, adopting a common currency as a common peg is not optimal when the anchor country fails to be the prominent partner outside the region, as evidenced by the Asian crisis: the appreciation of the US dollar from 1995 to 1997 is often cited as one of the causes of the 1997 crisis (Ito, Ogawa and Sasaki, 1998). Finally, choosing a foreign anchor means adopting the corresponding monetary policy. Hence, there should not be too much asymmetry in business cycles with the anchor country, and optimum currency criteria should be taken into account.

From the literature on the choice of an anchor currency, it can be concluded that the euro is a more straightforward anchor than the dollar. This is because CEECs and Northern African countries carry out most of their trade with the euro zone (see Appendix 4); they also display business cycles and (for some of them) specialization patterns which are rather close to those of the euro zone (Boone and Maurel, 1999; Bénassy-Quéré and Lahrèche-Révil, 1999). In contrast, Asian countries would better peg their currencies to baskets of foreign currencies (Williamson,1999; Bénassy-Quéré, 1999b). Lastly, the external trade of the largest South-American countries is relatively well distributed geographically, which would again justify using baskets rather than single anchors.

Using a common peg could be achieved without regional co-operation around the euro-zone, whereas the lack of regional co-operation constitutes a major impediment in Asia or in South America. Even though a common basket can be defined relatively easily, its use would necessitate a high degree of political commitment. In the absence of regional co-operation, the dollar can be used as a second best option (Bénassy-Quéré, 1999b; Ito et al., 1999). Each country then optimizes considering the exchange-rate policy of its partners as given. Theoretically, this gives birth to multiple equilibria (pegs on the yen, on the euro, on the dollar, on a basket, etc). In practice, history and politics have lead most countries to focus on the US dollar.

Hence, a peg on a single currency (contrasting with a peg on a common basket) remains an attractive system due to its low requirement in terms of co-operation, all the more so if the peg is "soft", i.e. without compulsory interventions. In addition, this type of peg is more verifiable by market participants, which grants it with more credibility (Frankel et al., 1999), although it can yield bad incentives in terms of hedging. 
The tendency for countries that have been hit by crises to come back to de facto pegs on the dollar (as evidenced in Table 2) can be understood in this context. The use of the euro could spread for the same reasons. But in regions like Asia or South America, pegs on the dollar are by no way optimal and are therefore only a stopgap compared to regional co-operation which could be organized around common baskets of foreign currencies. We study below how such a co-operation could be organized.

\subsection{Institutions for regional integration}

Classical analyses of monetary regionalism, from the early work of Richard Cooper (1975) to Canzoneri and Henderson (1991), highlighted the superiority of cooperation (i.e. joint optimization of a common loss function) over coordination (i.e. the selection of a specific Nash equilibrium). Coordination only rests on information sharing, whereas cooperation rests on a commitment not to accommodate only domestic shocks.

It can be strongly argued that in order to be credible and to avoid renegociation, such commitments have to be backed by binding agreements such as treaties or supranational bodies. More generally, some have argued that the essence of money is political and that monetary relations reflect permanent bargaining and, ultimately, the hierarchy of power between sovereign states (Cohen, 2000). At any rate, the political economy dimension is key to understand the dynamics of monetary integration.

\section{A. From coordination to cooperation}

The degree of formalization and constraint of regional agreements can be adjusted according to the desired degree of coordination.

Networks of personal relationships among monetary officials and government bureaucrats, discussion fora held on a regular basis, are first steps of cooperation and their usefulness should not be understated. Such coordination networks must cover the economic as well as the political dimension. This is because monetary and exchange rate policies are closely related to all other economic policies (fiscal policy, and also, as the Asian crisis has illustrated, banking regulation). Networks in the private sector are important too as factors of economic integration, facilitating intra-regional trade and investment. The development of local financial markets through the creation of new instruments, agreements between central banks to maintain the liquidity of markets and cross-quotation among marketplaces (as witnessed by the ongoing discussions between Hong Kong and Singapore) is also a useful complement to economic cooperation.

As for economic policy, the main aim of regional coordination should be to create peer pressure so as to give more transparency and more coherence to domestic policies. This applies to monetary, fiscal as well as to structural policies. It can also be helpful to coordinate reactions to common shocks hitting the region, for instance a large movement of the value of the main currencies. Indeed, ex-ante coordination of the reaction to macroeconomic shocks contribute to the stabilization of exchange rates (Coeuré and Pisani-Ferry, 2000), irrespective of whether coordination aims at reaching a global optimum or only at defending the existing institutions against shocks ("regime preserving" coordination in the words of Kenen, 1988).

Also, since the Mexican crisis, the IMF has sought to improve the availability of data on exchange rate reserves, public finances and the macroeconomic situation, leading to the enforcement in 1999 of a data dissemination standard ("SDDS") for all Member states. As the European experience has shown, coordination on statistical methods at a regional level can greatly help identifying statistical pitfalls and meeting global standards. 
These various initiatives could evolve towards cooperation under the face a more centralized decisionmaking process.

\section{B. History matters: lessons from Europe and Asia}

The weight of historical factors is evident in the case of Europe, where the process of economic, and then monetary integration is rooted in century-old political debates. As early as in the mid-nineteenth century, the French writer and politician Victor Hugo advocated a political union in Europe. After World War II, the so-called " founding fathers of Europe " had the ultimate goal to make a new war between France and Germany never to happen again. Asia provides a different example of a cooperation process which is obviously neither planned nor comprehensive, but where instruments have nevertheless been developed over years.

The European experience is a blend of all the elements mentioned above. Information sharing and peer pressure among government officials and central bankers have taken place since the inception of the Community in the framework of various committees, the more important for monetary matters being the Monetary Committee (renamed in 1999, the Economic and Financial Committee, and putting together officials from the 15 Member States, the ECB and the Commission). The European monetary system in place from 1979 to 1998 included a network of swap agreements between European central banks and with the Bank of International Settlements. The European system is also an interesting compromise from an institutional perspective, since it is at the same time federal (with a major impulse role of the Commission, and, in the monetary field, of the European Monetary Institute then the ECB) and inter-governmental (major decisions being taken by the Council of Ministers ${ }^{24}$ ). In this framework, political and monetary decisions have always closely interacted. During the 1992 and 1993 crises, decisions were determined by the overall economic and political context. The new exchange rate mechanism launched in 1999 explicitly conditions assistance by the ECB to the conduct of economic policies "geared towards stability" (European Council, 1997).

As early as in 1957 (the very year the Treaty of Rome was agreed in Europe), technical discussions were initiated among central banks from Asia and the Pacific region, the number of which has now reached twenty $\left(\right.$ SEANZA $\left.^{25}\right)$. Meetings of South East Asian central bank (SEACEN) have been organized since 1966 and were complemented in 1991 by a twice-yearly forum for technical discussion among eleven countries $\left(\mathrm{EMEAP}^{26}\right)$ and then, after the Mexican crisis, by a network of repo and currency swap agreements between central banks. Informal fora for macroeconomic discussion also exist: a short-lived "Asian G6" was launched in 1996 a few months before the financial crisis, and meetings of $\mathrm{APEC}^{27}$ or $\mathrm{ASEAN}^{28}$ finance ministers now take place on a regular

\footnotetext{
${ }^{24}$ Interestingly, the European exchange rate mechanism (in its 1979 as well as in its 1999 versions) is not an instrument of the Community but an intergovernmental agreement.

${ }^{25}$ SEANZA stands for South East Asia, New Zealand and Australia.

26 Executive meeting of East Asia and Pacific central banks: Hong-Kong, Malaysia, Indonesia and Thailand, later joined by Japan, Singapore and the Philippines.

${ }^{27}$ APEC is made of eleven Asian economies (Japan, Korea, the Philippines, Indonesia, Malaysia, Bruneï , Singapore, Thaï land, PR China, Taï wan and Hong Kong), three Pacific economies (Australia, New Zealand and Papouasia-New Guinea) and four American economies (Canada, Mexico, Chile and the US).

28 ASEAN is made of ten economies: Bruneï, Cambodia, Indonesia, Laos, Malaysia, Myanmar, the Philippines, Singapore, Thaï land and Vietnam.
} 
basis. ASEAN countries also met in 1999 together with the three regional powers, the People's republic of China, the republic of Korea and Japan, in the so-called "ASEAN+3" framework.

As pointed out by Kwan (1999), economic and financial integration with the rest of Asia was achieved so far mainly through the initiative of the private sector, with the development of trade and FDI flows. In recent years, however, public authorities throughout Asia have sought to give a new impetus to the integration process.

In several occasions, the Japanese government has expressed its wish to develop the international role of the yen, the main objective being apparently to counter the erosion of Tokyo as an international financial center. Concrete measures were taken to enhance the attractiveness of the yen as an international currency, such as the removal of all remaining foreign exchange restrictions as a part of the "big bang" of the Japanese financial system, and the introduction of new financial instruments denominated in yen.

The next step could be a regional monetary arrangement. Bayoumi, Eichengreen and Mauro (1999) underlined that the underlying political commitment is seen as a remote perspective. It seems however that such ideas have increasingly been tested by Asian politicians. Hong Kong Finance Secretary Donald Tsang suggested in October 1999 to create a common currency for Hong Kong and Singapore at a five or six year horizon. In addition, several Asian heads of state, among which the Malaysian prime minister Mahatir or the Philippino president Estrada, have favored at times a common currency in Asia. In the latter case, the main rationale does not seem to be an economic but rather a political one. Building on the European example, monetary union is seen as a catalyst to regional political cooperation.

More recently, ASEAN Finance Ministers at their meeting in Brunei in march 2000 rejected the idea of an «Asian Monetary Fund » but they invited Japan, Korean and China to join their existing currency swap agreement, and they agreed to strengthen regional surveillance and to develop an « early warning» system to prevent crises.

Political impediments are more frequently quoted than economic pros and cons to explain why such projects are envisaged only for the very long run ${ }^{29}$. It is of course recognized that heterogeneous stages of economic development and trade patterns make the definition of a monetary arrangement tricky, even though a careful analysis suggests that trade structures may matter less than it is frequently thought, as mentioned above in the case of the choice of a basket. But more importantly, as pointed out by Eichengreen (1997), a prerequisite is the settlement of long lasting political conflicts, some of which are inherited from World War II (notably between Japan, Korea and China), and others are due to ethnic or religious patterns.

Conversely, however, the widespread resentment across Asia towards the way G7 countries and the IMF have handled the 1997 crisis could have triggered the ongoing move towards regional coordination $^{30}$. We conclude from this discussion that the commitment to an intermediate regime has to be stronger than in the past, along two lines:

- First, give some guarantees of short term robustness, either domestic (foreign exchange reserves, flexibility in exchange rate management so as to limit the likelihood of macroeconomic misalignments, control of short term inflows) or external (regional or international assistance in case of a speculative crisis).

\footnotetext{
${ }^{29}$ Bergsten (2000) is more optimistic concerning the timetable, viewing the building of regional institutions as the "new Asian challenge".

${ }^{30}$ This point has been made to us by Randy Henning.
} 
- Second, indicate clearly the long term objective of any exchange rate regime, in the framework of an overall economic and political strategy, taking into account regional interactions.

\section{Vertical integration of the International Monetary System}

Global externalities are created by inter-regional trade links, contagion on global financial markets and implicit or explicit guaranteed awarded by the international community. These externalities raise the need for a vertical integration of the IMS.

First, in order to be robust in a world of mobile capital flows, monetary arrangements have to be complemented by mechanisms of crisis prevention. But such mechanisms can only be global, due to contagion effects on global financial markets (see the diffusion of the 1997/98 crisis throughout emerging markets), to negative spillovers generated by local crises for the world economy, and to the ever increasing size of emergency assistance packages. Besides, cooperation in itself increases each country's dependency on its neighbors' fundamentals, thus the scope for contagion effect in the case of a crisis (Loisel and Martin, 1999).

Then, since a radical overhaul of the IMS is very unlikely in the years to come, cooperation has to be consistent with existing surveillance and crisis management, which is now organized around the IMF and is likely to remain so. Indeed, the current trend is to refocus the IMF on surveillance and emergency loans. It is true that the most recent crises (Korea, Brazil) have given an increased role to bilateral credit lines, but this was mainly because of the limited financial capacity of the Fund, the coordinating role of which has never be questioned.

Creating "regional monetary fund" 29 would thus entail the risk of insufficient coordination at the global level. Moreover, the political implications of such devices would be enormous and uncontrolled since they would increase the power of local creditor countries, giving them a role similar to that of G7 countries at a regional level. Another solution, "decentralizing" the IMF in regional, autonomous branches, would create moral hazard as long as financing is ultimately borne by the G7.

A more modest step would be to increase the regional dimension of IMF surveillance and assistance. The Fund could perform "article four"-type surveillance not only for Member states but also for economic regions ${ }^{30}$. Statistical data on regional interactions (for instance matrices of bilateral trade and financial flows) could be collected and published in the framework of the SDDS. The IMF could also deepen the regional dimension of adjustment programs and have it included in the conditionality of its financial instruments, in particular the "contingent credit line" created in 1999 to prevent liquidity crises in otherwise "virtuous" economies.

The preceding analysis leads us to a number of practical suggestions to improve the international monetary system, along three main lines.

\footnotetext{
${ }^{29}$ In 1995, the President of the Federal Reserve Bank of Australia, Bernie Fraser, proposed an "Asian BIS". In 1997, the Japanese government proposed an "Asian monetary fund", then withdrew this proposal.

${ }^{30}$ Such surveillance has been undergone since 1999 on an informal basis for the monetary and exchange rate policies of the euro area. The crucial difference between surveillance of the euro area and, say, Latin America, is that euro area is envisaged by the Fund as a whole, as it is by the ECB, whereas the would-be "Latin America Article IV" should give a particular attention to the consistency of individual exchange rate policies and to intra-regional interactions.
} 


\section{CONCLUSION}

In the paper, we investigated the choices of an exchange rate regimes in emerging market economies, from both positive and normative points of view. First, we could not find in exhange rate data an evolution towards the so-called «two-corner solutions » as a result of the Asian crisis. Indeed, we evidenced the great resilience of the international monetary system. Second, we found that a move towards monetary block-floating could increase by a significant margin the volatility of the euro/dollar exchange rate. Third, judging from recent history and investigating the long term dynamics of monetary arrangements, we found that intermediate exchange rate regimes could be viable provided that they are part of a comprehensive stategy (1) over time, as a transition towards a monetary union and (2) across countries, as a complement to regional policy coordination.

These normative findings obviously lack rigourous behavioural foundations. The next step should be to confront them to a model of short run and long run exchange rate regime choice with sound micro foundations. The transition from a regime to another one could then be derived. Also, as noted above, the implications of capital mobility have not been fully investigated in the present paper and should be incorporated into the model. We believe these questions are promising avenues for future research and should help formulate more rigorously the ongoing debate on exchange rate regimes in emerging market economies. 


\section{REFERENCE}

AgGaRWAL, R. and M. MOUgouÉ (1993), « Cointegration among Southeast Asian and Japanese Countries: Preliminary Evidence of a Yen Bloc?», Economic Letters 41, 161-166.

ANTHONY, M.L. and A. HUGHES HALLETT (2000), « Is the case for economic and monetary union in the Caribbean realistic?», The World Economy 23, pp. 119-144.

ARTIS, M. and J. MÉLITZ (1999) «Trade and the Number of OCAs in the World», Open Economies Review, 9:S1, 537-567.

BANK OF INTERNATIONAL SETTLEMENTS (1999), Central Bank Survey of Foreign Exchange and Derivatives Market Activity, 1998, May.

BAYOUMI, T. and B. EICHENGREEN (1999), « Is Asia an Optimum Currency Area? Can It Become One? » in: Collignon, S., J. Pisani-Ferry and Y.-C. Park, eds., Exchange Rate Policies in Asian Emerging Countries (Routledge, London).

BAYOUMI, T., B. EICHENGREEN and P. MAURO (1999), « On regional monetary arrangement for ASEAN», ADBI-CEPII-KIEP International Conference on Exchange Rate Regimes in Emerging Market Economies, Tokyo, December 17-18, available on www.cepii.fr.

BÉNASSY-QUÉRÉ A. (1999a), « Exchange Rate Regimes and Policies: and Empirical Analysis », in: Collignon, S., J. Pisani-Ferry and Y.-C. Park, eds., Exchange Rate Policies in Asian Emerging Countries (Routledge, London).

BÉNASSY-QUÉRÉ, A. (1999b), « Optimal Pegs for East-Asian Currencies », Journal of the Japanese and International Economies 13, March.

BÉNASSY-QUÉRÉ, A., L. FONTAGNÉ and A. LAHRÈCHE-RÉVIL (1999), "Exchange-rate strategies in the competition for attracting FDI", CEPII Working Paper 99-16.

BÉNASSY-QUÉRÉ, A. and A. LAHRÈ CHE-RÉVIL (1999), « L'euro comme monnaie de référence à l'est et au sud de l'Union européenne », Revue Economique, 50 (2), 1185-1202.

BERGSTEN, C.F. (2000), «The New Asian Challenge», Institute for International Economics Working paper, 00.04, March.

BOONE, L. and M. MAUREL (1999), «L'ancrage de l'Europe centrale et orientale à l'Union européenne », Revue Economique, 50 (2), 1123-1138.

CANZONERI, M. and D. HENDERSON (1991), «Monetary policy in interdependent economies, a game-theoretic approach», MIT Press.

COURÉ, B. and J. PISANI-FERRY (2000) “ The euro, the yen and the dollar: the case against benign neglect ", forthcoming in A. Swoboda and P. Kenen, ed., Key Issues in the Reform of the International Monetary and Financial System, International Monetary Fund.

COHEN, B. (2000), "Money and power in world politics", forthcoming in Th. Lawton et al., Eds., Strange Power, Ashgate Publishing, also available on www.hssc.ucsb.edu/ cohen/.

COLLIGNON, S. (1999), « Bloc floating and exchange rate volatility: the causes and consequences of currency blocs », in: Collignon, S., J. Pisani-Ferry and Y.-C. Park, eds., Exchange Rate Policies in Asian Emerging Countries (Routledge, London). 
CONSEIL EUROPÉEN (1997), « Résolution du CE sur l'établissement d'un mécanisme de change en phase III de l'UEM ».

COOPER, R. (1975), «Prolegomena to the choice of an International Monetary System », Inernational Organization, 69-84.

DORNBUSCH, R. and F. GIAVAZZI (1999), « Hard currency and sound credit, a financial agenda for Eastern European Countries », mimeo.

EICHENGREEN, B. (1997), «Is there a monetary union in Asia's future?», Brookings Review, Spring.

EICHENGREEN, B. (1999), Toward a New International Financial Architexture, Institute for International Economics, Washington D.C.

EICHENGREEN, B. and T. BAYOUMI (1999), « Is Asia and optimum currency area? Can it become one? Regional, global and historical perspectives on Asian monetary relations », in: Collignon, S., J. Pisani-Ferry and Y.-C. Park, eds., Exchange Rate Policies in Asian Emerging Countries (Routledge, London).

FRANKEL, J.A. (1993), «Is Japan Creating a Yen Bloc in East Asia and the Pacific? », in Regionalism and Revalry: Japan and the US in Pacific Asia, J.A. Frankel and M. Kahler eds., University of Chicago Press, 53-85.

FRANKEL, J.A and S.-J. WEI (1994), « Yen Bloc or Dollar Bloc? Exchange rate Policies in East Asian Economies », in Macroeconomic Linkages: Savings, Exchange Rates and Capital Flows, T. Ito and A. Krueger eds., University of Chicago Press.

FRANKEL, J. (1999), « No single currency regime is right for all countries or at all times », NBER working paper 7338, September.

FRANKEL, J.A. and S.-J. WEI (1995), « Emerging Currency Blocs », in The International Monetary System: its Institutions and its Future », H. Genberg ed., Springer, Berlin, 111-143.

FRANKEL, J.A., S. SCHMUKLER AND I. SERVÉN (1999), «Verifiability: a Rationale for the Failure of Intermediate Exchange Rate Regimes », mimeo.

FRATIANNI, M. and J. VON HAGEN (1990), « The European Monetary System ten years after », Carnegie-Rochester Conference Series on Public Policy 32, 173-241.

GALATI, G. (1999), « The Dollar-Mark Axis », BIS working paper No 74, August.

GIRARDIN, E and V. MARIMOUTOU (1997), « Common Movements of Asian Currencies vis-àvis European Currencies », International Research Seminar on Economic Relations Between Europe and East Asia, Nîmes, 19-20 June.

GROS, D. and J. WEINER (2000), « A note on measures of openness, or exposure to external shocks », Centre for European Policy Studies, Brussels.

HONOHAN, P. (1997), « Miniblocs and fringe currencies in the EMU? », CEPR Discussion Paper 1704.

HONOHAN, P. and P. R. LANE (1999), « Pegging to the dollar and the euro », mimeo.

ITO, T., E. OGAWA AND Y. SASAKI (1998), « How did the dollar peg fail in Asia? », NBER Working Paper 6729. 
ITO, T., E. OGAWA and Y. SASAKI (1999), «On the desirability of a regional basket currency arrangement », ADBI-CEPII-KIEP International Conference on Exchange Rate Regimes in Emerging Market Economies, Tokyo, December 17-18, available on www.cepii.fr.

JADRESIC, E., P. MASSON, P. and P. MAURO (1999), « Exchange rate regimes of developing countries: global context and individual choices », ADBI-CEPII-KIEP International Conference on Exchange Rate Regimes in Emerging Market Economies, Tokyo, December 17-18, available on www.cepii.fr.

KENEN, P. (1988), Managing Exchange Rates, Council on Foreign Relations, New York.

KINDLEBERGER, CH. P. (1973), The World in Depression, 1929-1939, Allen Lane, Penguin Books Ltd.

KRUGMAN, P. (1984), « The international role of the dollar: theory and prospect », in J. Bilson et R. Marston eds., Exchange Rate Theory and Practice, University of Chicago Press.

KWAN, C.-H. (1999), « Towards a Yen block in Asia », NRI Quarterly, Summer.

LEVASSEUR, V. and F. SERRANITO (1996), « Y a-t-il formation d'une zone yen dans la région Asie-Pacifique? », Economie Internationale, $n^{\circ} 66,2^{\text {nd }}$ quarter, 81-108.

LEVY, YEYATI, E. and F. STURSENEGGER (1999), « Classifying exchange rate regimes: deeds vs words », Mimeo, Universidad Torcuato di Tella.

LOISEL, O. and PH. MARTIN (1999), « Coordination, cooperation, contagion, and currency crises », CEPR Discussion Paper \#2075.

MASSON, P. (1999), « Monetary and exchange rate policy of transition economies of Central and Eastern Europe after the launch of EMU», IMF working paper, July.

MASSON, P. (2000), « Exchange-rate regime transitions », Mimeo.

MCKINNON, R. (1963), “Optimum currency areas”, American Economic Review, 53.

MUSSA, M., MASSON P., SWOBODA, A., JADRESIC, E., MAURO, P. and A. BERG (2000), « Exchange-rate regimes in an increasingly integrated world economy », IMF Occasional Paper, forthcoming.

PARK, Y-C., Y.J. WANG and C.S. CHUNG (1999), « Exchange rate policies in Korea: has exchange rate volatility increased after the crisis? », ADBI-CEPII-KIEP International Conference on Exchange Rate Regimes in Emerging Market Economies, Tokyo, December 17-18, available on www.cepii.fr.

OHNO, K. (1999), « Exchange Rate Management in Developing Asia », ADB Institute Working Paper, January.

SADEH, T. (1997), "The Economic Desirability of Middle-Eastern Monetary Cooperation", The World Economy, 20(6), September, 809-828.

SUMMERS, L. (1999), « Testimony before the Senate Foreign Relations Subcommittee on International economic policy and export/trade promotion », 27 January.

TAKAGI, S. (1996), « The yen and its East Asian neighbors, 1980-95: cooperation or competition?, NBER working paper nb 5720, août. 
WILLIAMSON, J. (1999), « The case for a common basket peg for East Asian currencies », in: Collignon, S., J. Pisani-Ferry and Y.-C. Park, eds., Exchange Rate Policies in Asian Emerging Countries (Routledge, London).

WILLIAMSON, J. (1983), The Exchange Rate System, Institute for International Economics. 


\section{APPENDIX 1}

\section{A general identification method for monetary anchors}

This new method gives a symmetrical role to the three main currencies and it avoids the choice of an arbitrary numeraire. It also allows simple hypothesis testing.

\section{- Geometrical characterization}

Let $\mathrm{X}_{\mathrm{it}}=\left(\mathrm{e}_{\mathrm{i} \$}, \mathrm{e}_{\mathrm{ie}}, \mathrm{e}_{\mathrm{iy}}\right)_{\mathrm{t}}$ ' be a three-dimensional vector where $\mathrm{e}_{\mathrm{i} \$}$ is the log-variation of the exchange rate of currency $i$ against the US dollar, $\mathrm{e}_{\mathrm{e}}$ against the euro and $\mathrm{e}_{\mathrm{iy}}$ against the yen.

Currency $i$ is pegged on a basket made of the dollar, the euro and the yen if and only if, irrespective of currency $j$ taken as a numeraire, the exchange rate of $i$ against $j$ is a geometrical average of the three big currencies against $j$, namely:

$$
\forall \mathrm{t},\left(\mathrm{e}_{\mathrm{ij}}\right)_{\mathrm{t}}=-\alpha_{\mathrm{i}}{ }^{\prime} \mathrm{X}_{\mathrm{jt}}+\beta_{\mathrm{i}}
$$

with $\alpha_{i}=\left(\alpha_{i \$}, \alpha_{i e}, \alpha_{i y}\right)$ ' and $\alpha_{i \$}+\alpha_{i e}+\alpha_{i y}=1$. Substituting $e_{j \$}$ with $\left(e_{i \$}-e_{i j}\right)$ leads to:

$$
\forall \mathrm{t},\left(1-\alpha_{\mathrm{i} \$}-\alpha_{\mathrm{ie}}-\alpha_{\mathrm{iy}}\right)\left(\mathrm{e}_{\mathrm{ij}}\right)_{\mathrm{t}}=-\alpha_{\mathrm{i}}{ }^{\prime} \mathrm{X}_{\mathrm{it}}+\beta_{\mathrm{i}}
$$

thus finally:

$$
\forall \mathrm{t}, \alpha_{\mathrm{i}}{ }^{\prime} \mathrm{X}_{\mathrm{it}}=\beta_{\mathrm{i}}
$$

Geometrically, in a three-dimensional space where Cartesian coordinates are the exchange rates against the main currencies, currency $i$ is pegged with weights $\left(\beta_{\mathrm{i}}\right)$ if the path of $\mathrm{X}_{\mathrm{it}}$ is confined to a plan orthogonal to $\alpha_{\mathrm{i}}$. 
CEPII, document de travail $n^{\circ} 2000-10$

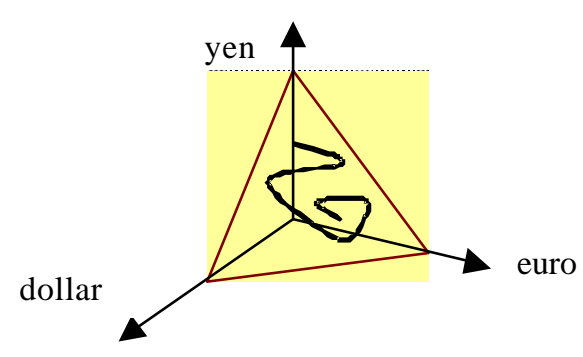




\section{- $\quad$ GMM estimation}

Since the peg can be described as an orthogonality condition, it is particularly suited to a method of moments. The generalized method of moments (GMM) estimator of $\alpha_{i}$ is:

$$
\hat{\mathrm{a}}_{\mathrm{i}}=\underset{\alpha, \beta}{\operatorname{Argmin}} \mathrm{J}_{\mathrm{T}}(\alpha, \beta)=1 / \mathrm{T}^{2} \quad\left(\Sigma_{\mathrm{t}}\left(\alpha^{\prime} \mathrm{X}_{\mathrm{it}}\right) \cdot \mathrm{Z}_{\mathrm{t}}\right)^{\prime} \mathrm{W}_{\mathrm{T}}^{-1} \quad\left(\Sigma_{\mathrm{t}}\left(\alpha^{\prime} \mathrm{X}_{\mathrm{it}}-\beta\right) \cdot \mathrm{Z}_{\mathrm{t}}\right)
$$

$Z_{t}$ is a (facultative) vector of $k$ instruments which should be correlated to endogenous variables and orthogonal to innovations $\alpha_{i}^{\prime} X_{i t} \cdot W_{T}$ is an estimation of the variance of the residuals $\left(u_{t}\right)$ with $u_{t}=\left(\alpha^{\prime} X_{i t}\right) Z_{t}$, that is, $(2 \pi$ times $)$ the spectral density of $u_{t}$ at zero frequency. When exchange rates are observed at the end of each period, one has to use an heteroskedasticity and autocorrelation-consistent estimator, such as the one proposed by Newey et West (1987).

The variance of estimator $\hat{a}_{\mathrm{i}}$ is:

$$
\mathrm{V}\left(\hat{\mathrm{a}}_{\mathrm{i}}\right)=\mathrm{T}^{-1}\left\{\mathrm{~g}_{\mathrm{T}}{ }^{\prime} \mathrm{W}_{\mathrm{T}}^{-1} \mathrm{~g}_{\mathrm{T}}\right\}^{-1} \quad \text { with }
$$

$$
\mathrm{g}_{\mathrm{T}} \quad=\quad \mathrm{T}^{-1} \Sigma_{\mathrm{t}} \quad \partial\left(\left(\alpha^{\prime} \mathrm{X}_{\mathrm{it}}\right) \cdot \mathrm{Z}_{\mathrm{t}}\right) / \partial \alpha^{6} \quad=\quad \mathrm{T}^{-1} \Sigma_{\mathrm{t}} \mathrm{X}_{\mathrm{it}} \otimes \mathrm{Z}_{\mathrm{t}}
$$

Hansen's $J$ statistic is:

$$
\mathrm{J}=\mathrm{T} . \mathrm{J}_{\mathrm{T}}\left(\hat{\mathrm{a}}_{\mathrm{i}}\right) \quad \sim \chi^{2}(\mathrm{k}-1) \quad \text { under the null } \mathrm{E}\left(\alpha^{\prime} \mathrm{X}_{\mathrm{i}}\right) \cdot \mathrm{Z}=0 .
$$

If the instruments are correct, rejecting the null hypothesis can be interpreted as the absence of a peg against the euro, the dollar and the yen, thus as free floating or pegging on another currency. However it can also be due to inadequate instruments.

$\underline{\text { Remark: }}$ it is necessary to set the constraint $\alpha_{\mathrm{i} \$}+\alpha_{\mathrm{ie}}+\alpha_{\mathrm{iy}}=1$ in the estimation stage since $\alpha_{\mathrm{i}}$ is identified only as a direction and can otherwise be multiplied by an arbitrary factor.

\section{- $\quad$ Restriction testing}

It is straightforward to test for the presence of $\mathrm{p}=1$ or 2 linear restrictions on $\alpha_{i}$ :

$$
\begin{array}{lllllllll}
\Gamma . \alpha_{i}=0 & \text { where } & \Gamma & \text { is } & \text { a } & \text { p } & \text { x } & 3 & \text { matrix }
\end{array}
$$

The likelihood ratio test is then:

$$
\xi=\mathrm{T} .\left(\mathrm{J}_{\mathrm{T}}\left(\hat{\mathrm{a}}_{\mathrm{i}}^{c}\right)-\mathrm{J}_{\mathrm{T}}\left(\hat{\mathrm{a}}_{\mathrm{i}}^{n c}\right)\right) \quad \sim \quad \chi^{2}(\mathrm{p})
$$


where $\hat{\mathrm{a}}_{i}^{c}$ is estimated using the constrained model and $\hat{\mathrm{a}}_{1}^{n c}$ using the unconstrained model ${ }^{17}$. This can be applied to dollar pegs $\left\{\alpha_{\mathrm{ie}}=\alpha_{\mathrm{iy}}=0\right\}$, euro pegs $\left\{\alpha_{\mathrm{is}}=\alpha_{\mathrm{iy}}=0\right\}$ or yen pegs $\left\{\alpha_{\mathrm{ie}}=\alpha_{\mathrm{is}}=0\right\}$.

\section{- $\quad \underline{\text { Application }}$}

The sample comprises 119 currencies of sovereign states, economic regions (Hong Kong) or currency areas (the euro area, the CFA franc area) ${ }^{31}$. Weekly nominal exchange rates were taken from Reuters, by which they were measured at the closing of each trading week. Two sub-periods were defined:

- the first period begins after the Mexican crisis and ends before the devaluation of the Thai baht (7 May 1995-29 June 1997 i.e. 110 observations),

- the second period begins at the end of the most severe tensions on financial markets and ends before the millenium change (4 October 1998-26 December 1999 i.e. 65 observations).

17 currencies were discarded on the first sub-period ${ }^{32}$ due to missing data or to the existence of exact pegs which make the estimation impossible, in which case the coefficients were added by hand. 8 currencies were discarded in the second sub-period ${ }^{33}$ for similar reasons.

Instruments include a constant and 4 lags of endogenous variables. Autocorrelation was corrected up to 4 lags using a Bartlett window (Newey and West, 1987) ${ }^{34}$.

${ }^{31}$ The computer code and data can be provided on request by the authors.

${ }^{32}$ Cambodia, North Korea, Congo, Guinea, Guyana, Kazakhstan, Iran, Lesotho, Latvia, Lybia, Lithuania, FYROM, Maldives, Nigeria, Salvador, Somalia and Syria.

${ }^{33}$ Cambodia, North Korea, Congo, Iran, Iraq, FYROM, Myanmar and Trinidad and Tobago.

${ }^{34}$ A technical difficulty is that the metric $\mathrm{W}_{\mathrm{T}}$ may differ slightly in the constrained and unconstrained estimations because it is estimated iteratively, beginning with an identity matrix then, at each stage, as the variance of the residuals yielded by a previous stage. 